\title{
Using Applied Theatre as a Tool to Address Netizenship
}

\author{
Fadi Fayad Skeiker ${ }^{1}$ \\ ${ }^{1}$ Theatre Arts Department, University of Jordan, Amman, Jordan \\ Correspondence: Fadi Fayad Skeiker, Theatre Arts Department, University of Jordan, Amman, Jordan. Tel: \\ 96-27-9547-6256. E-mail: f.skeiker@ju.edu.jo; fadiskeiker@hotmail.com
}

\author{
Received: October 13, 2014 Accepted: November 31, 2014 Online Published: January 29, 2015 \\ doi:10.5539/ies.v8n2p212 URL: http://dx.doi.org/10.5539/ies.v8n2p212
}

\begin{abstract}
This paper charts the ways in which a researcher uses applied theatre practice as a tool to address netizenship issues in the advancement of digital age by documenting a workshop he co-facilitated with graduate students at the University of Porto during the Future Places conference in 2013. The workshop used applied theatre both to catalyze intellectual discussion on netizenship and to create creative performance that embodied the concepts discussed. Applied Theatre approach is used to exploring issues of netizenship because, similar to social media, it blurs the lines between performer and audience. The results and analysis of the workshop demonstrate that applied theatre was a successful tool to address netizenship issues.
\end{abstract}

Keywords: applied theatre, participatory theatre, theatre workshop, netizenship, citizenship, digital world

\section{Introduction}

Traditionally speaking, citizenship implies a legal status within a nation/state, and political, social and civil rights as defined by that nation's laws. An array of neighborhoods, political parties and communal/social clubs were established to bring together affiliated citizens face to face to form NGOs and civic interaction that would enhance/foster connecting citizens in local communities. The spread of digital media, however, and internet invite citizens to reconsider their citizenship behaviours (Bimber, 2006; Hardy \& Scheufele, 2007). Citizens start to assert their legal rights and build their social connections through social media platforms and thus forming a new form of citizenship that will be addressed in this paper as netizenship. A netizen is defined generally as a user/citizen of the internet (Omotoyinbo, 2014). Nowadays, cyberspace becomes a site for forming new identities, new social connections, and new meanings for belonging-a site for A "new social institution" (M. Hauben \& R. Hauben, 1998). With social media being the epitome of communication and connection to others and their lives (Castro, 2008), we start to find netizens coming together through their media connection at times to replace and at other times to complement lively face-to-face participation with a digital one.

While the notion of netizen is being developed and practiced, theatre in general-and applied theatre in particular -can be used as a creative instrument that can help us build a narrative for this phenomena and allow us to question its effects. Applied theatre offers a site that can ask, embody, and stimulate dialogue about an issue. Although the two forms seem drastically different, applied theatre shares core characteristics of operating within digital world. First, both deal with the realm of representation, as people present a persona to their public in both applied theatre and the internet. Also, both merge the performance site with the spectators' site. In applied theatre, more than in conventional theatre, the lines between performer and spectator are blurred, which is why the influential proponent Boal (1985) called participants "spect/actors". Similarly, interdisciplinary scholar Kathleen Irwin (2011) states that the internet offers a new site for representation that blurs the distinction between the watched and the watcher. These reasons suggest why using applied theatre as an instrument might contribute to the growing discourse on netizenship. This article traces a project, a workshop in a festival, which asks the following questions: Can applied theatre be helpful in initiating a discussion about the effects of internet on social lives? In what ways can applied theatre interweave art and netizenship, or expressive communication and netizenship?

\subsection{Applied Theatre}

Applied Theatre is broadly defined as the use of theatre techniques among a specific community to encourage the members of that community to rethink collectively about, and embody, a specific issue. Applied Theatre researcher Taylor (2003) proposes that Applied Theatre helps in facilitating a dialogue, healing an emotional 
wound, or processing a specific issue of significant importance within a community. Taylor argues that applied theatre "operates from a central transformative principle that shares much with other participatory and community theatre movements, where a central emphasis is on the applications of theatre to help people reflect more critically on the kind of society in which they want to live" (Taylor, 2003, p. 1). As a teaching method, the form can therefore be useful for stimulating thinking about netizenship and community. In applied theatre, even though there might be a final product at the end, the focus is still centered on the process and on the journey of learning and discovery. The pedagogical approach emphasizes asking the learners questions, rather than presenting them with answers, as happens more in traditional didactic approaches to teaching. Most scholars and practitioners who write about applied theatre agree that the function of Applied Theatre is not necessarily to create a performance at the end of the work, but rather to create dialogue and opportunities for the community to reflect upon the issue or concern being discussed through that performance. It serves as a means of giving voice where people are not heard and to make them more articulate and expressive about their problems (Taylor, 2003). In the words of Taylor, "Applied Theatre offers a space where "individuals connect with and support one another and where opportunities are provided for groups to voice who they are and what they aspire to become" (Taylor, 2003, p. xviii).

\subsection{Future Places (Note 1)}

An applied theatre workshop took place in Future Places, a festival that has recurred every year since 2008 in Porto, Portugal (Note 2), which explored the relation of Digital Media to culture, and the evolution and development of this relationship. The festival is a meeting point for widely diverse participants, drawn from all disciplines and fields of knowledge and experience, which showcases their artistic talents and encourages artistic performances that reflect perspectives on the conference theme. Performances aim to transform both the approach of the performance makers and the attending audience on certain issues. In the 2013 Future Days Festival (Note 3), for instance, the theme was citizenship and how it emerges digitally and socially, as well as how the two interplay to yield certain emotions and perspectives. Future Places is a journey, showcasing the journeys of others by bringing in an entire new understanding that will lead to future places. As an Applied Theatre practitioner, I presented a workshop at the Festival with a co-facilitator, Dr. Susan Todd, a lecturer in St. Edwards University in Austin, Texas, and the Director of Weird Sisters Women Collective Theater in Austin.

\section{Key Concepts and Literature Review}

The following two concepts are used to lay the foundational themes of the workshop, and complement the concepts participants discussed during the workshops:

\subsection{Participatory Theatre}

The Progressive use of theatre for social purposes has been theorized mainly by the artists or community organizers who use the theatre techniques in their practice, although they have always been influenced by social movements, activism, and social theory. One key model is Augusto Boal's (1985) Theatre of the Oppressed technique in which theatre can be used as a tool to address social issues. In Theatre of the Oppressed, Boal challenges some theatre theories of the past, especially the relationship between the spectator and the stage. Boal shows how ruling classes employed traditional theatre to take control out of the hands of ordinary citizens, using the example of Greek drama. He then presents Brechtian and Marxian theatre and explains how they reverse this trend. Theatre of the Oppressed is divided into two parts: the first part is theoretical where he critiques the theories of Western Drama based on Aristotle and lays out his own theory and concepts; the second part is an account of Boal's work with the People's Theater in Peru, and his experiments in the Arena Theater of Sao Paulo, Brazil. Boal regards his Theatre of the Oppressed techniques as stimuli for change: "The theatre is not revolutionary itself, but it is surely a rehearsal for the revolution" (Boal, 1985, p. 122). In Boal's work, the community usually is facing a socio/political challenge, and theatre becomes a tool to allow citizens to civically dialogue about this challenge. Similar to Boal's work is Rohd's (1998), which offers an outline for creating an applied theatre program. Rohd believes that everyone can participate in this kind of work, and provides a model that can be adapted across range of subject matter. According to Rohd, theatre training is usually done in three parts: warm up, bridge-building activities and then activating material. The focus of this kind of theatre is on the community, using theatre as a tool to create social bonds and belonging; all of these themes were examined in the Future Places workshop within the framework of social media, and the advancement of the internet.

\subsection{Netizenship}

Netizenship can be described as the practices (social, political, etc) that internet users engage in on the internet. Film scholar Mark Poster defines netizen by comparing it to citizen of the nation whereas a netizen is the subject of the cyber state. Media scholar Mackinnon (2012) claims that it is "no longer sufficient for people to assert 
their rights and responsibilities as citizens of nation-states" (p. 201). She calls for the need for people to assert themselves as netizens. Her call came as an acknowledgment of the growth of the internet and its effects on people's social and political behavior. Social studies scholar Chachage (2010) also acknowledges netizenship practice as an empowerment tool for civil society organizations. Education scholar Özlem (2014) goes further by connecting netizenship to civic virtues. He argues, for example, that social studies teachers should be role models as both citizens and netizens. Netizenship practice is not restricted to political obligations or education; there are many channels netizens can use to affect public policies, such as blogs, online campaigns, and others. Also, because netizens form communities using social media platforms such as Facebook and Twitter, such communities are international since they do not, for the most part, limit themselves to geographical locations; netizens also use social media platforms to meet new people and expand their social circles. Social connections most recent site is the virtual where netizens build social networks, maintain social ties and develop social empathy for each others, all within the realm of the virtual. The question is, to what extent was netizenship practice able to replace traditional live face-to face social capital practice developed by citizens?

\section{Methodology}

The two facilitators in this workshop adopted the work of both Boal and Rohd to create a systematic method for helping participants approach their questions: first, by getting them engaged in physical activities that force them to focus on human interaction instead of electronic devices; then asking them to be immersed in actual chat sessions in real time during the workshop, which were used for constructing stories based on their chats; and finally, embodying the stories in performances. The workshop was divided into two parts: the first part lasted for two days and was dedicated to brainstorming and framing concepts and themes. The second part was stretched over three days where participants acted out their ideas into stories, to collectively create a performance based on the ideas that were generated in the first two days. There were about 20 participants on the first day and 10 who participated in the performance. Most of the participants were recruited through the conference organizers, and varied in being graduate students (MA and Ph.D students at the Multimedia Design program at University of Porto) and theatre artists from the Porto community. Expertise and professionalism was not a criterion, as variety and diversity were crucially needed to reflect as many layers of societies as possible. Workshop facilitation was divided between the author who focused on leading the session for generating ideas, and Dr. Todd who helped in writing the final script of the stories produced by participants. Both facilitators collaborated with participants to direct the performance. While leading the workshop, the facilitators asked the participants to engage in real live "chats" during the workshop, meaning that participants were allowed to chat on social media platform during the time of the workshop when they were building up a story for their performance. These live chats were used to be included in the story. During the time of the workshop and while participants were engaged real life chats, the facilitators noted the participants' involvement in what Charnet and Veyrier (2008) call "parallel activities", where participants were checking their emails and browsing websites while they were engaged in executing the instructions of the facilitators.

\section{Workshop Main Procedures}

\subsection{Personality Signature Improvisation}

Theatre workshops begin with warm up exercises, which resemble group games. For the first warm-up of this workshop, the object of the game is for each person to move her body in a distinct and unusual way while saying her name. Participants stand in a circle, and each will perform her name and movement and all other participants will repeat her sound and movement. The simple exercise usually creates laughter among the participants and in turn generates familiarity, collectivity and bonding. This game forces participants to engage in a bodily experience that moves them away from their electronic devices. This exercise allows participants to temporarily drift away from practicing their habitual virtual "parallel" activities on line, which usually includes checking their emails and social media updates.

\subsection{Join Me If}

In the next exercise, another common warm-up, the entire group stands in one line on one side of the room, side by side, facing the opposite wall. Anyone in the group crosses the room and says "Join me if you......like me!". The blank could be any statement, simple-"Join me if you chat for more than three hours every day like me!"-or complex-" Join me if you believe that the meaning of citizenship will be changed because of the advancement of new technology like me". Others follow the initiator across the room. Each participant will explain their positions. The exercise is important since it will bring people together based on certain similarities among a widely diverse group of participants. In this instance, participants raised and discussed topics about netizenship and virtual media: -what makes chatting in the virtual world different from a live conversation, the definition of 
citizenship and what defines active citizenship? Unlike the first exercise, which forces participants to go back to their inner selves to find out the way to present their bodies, this exercise is meant to bring them together and forms a sense of community among the group. They are invited to think about what connects them as a small group, and to find common threads that create a bond between them as a small group.

\subsection{Frozen Image}

In the next exercise, a group of participants would assume a collective position and freeze their bodies to express an idea, a concept, or a story. For example, three people might arrange themselves in postures that together express an image of "......". This activity will start as a general idea, a concept, or a story that can be built upon from the previous activity's discussion. Other participants observe each small group's collective pose and, with facilitator guidance, articulate what they observe, whether concrete (two people are blocking a third from moving forward) or abstract (it shows oppression). Such image work is always a safe start for participants who are not actors. It allows them to get into their bodies and be expressive in presenting/representing their ideas. Observing images and talking about them is the core of the game since each participant interprets the image in a way that is consistent with her own beliefs and not necessarily according to what the creator of the image intended. The facilitator's role is to keep guiding participants toward focused, objective observation, asking, "Is this really what you see?" Or, "are you projecting your ideas on what you see?" Participants are required to use frozen images as the backbone for their scene work later. This exercise is a step further in building a stronger bond among participants. They are not only instructed to build a frozen image, but they are also asked to construct a meaning for it, and they hear how clearly that meaning was conveyed to the rest of the participants who observe and interpret it. In this way, they are led to achieve the goal of the exercise in a collective way that furthers their social connections.

\subsection{Dramatizing the Stories}

After the warm-ups, the workshop advances to the next phase, which differs somewhat according to the emphasis of the event? In this case, the second part turned to themes related to digital media. Though in more ordinary applied theatre workshops, participants are urged to leave their devices off and aside, here devices were part of the exercises. The facilitators divided participants into three groups, asking each group to actually get involved in an online chat on one of the social media platforms with their friends/families. The mood of the group instantly shifted; the minute participants were given instructions to start chatting, each one went to their own electronic devices and got engaged in their virtual social interaction outside the room. The two facilitators started checking on participants and speaking to them one by one ("side coaching"), for example by asking the participants to divert the chat into asking their chat partners about whether this chat session seemed similar to their live interaction.

Leaving the creative work up to participants themselves, facilitators ask participants to use the earlier theatre games, especially the frozen image one, to help in dramatizing their scenes. Each group was responsible for developing a scene.

\section{Result/Performance}

\subsection{First Scene}

The final performance consisted of three major scenes: The first scene was about David, who decides to create a Facebook profile for himself, but with a different character-a profile that resembles what he wants to be in real life. In this scene, David, makes an online connection through his profile with a 17-year-old girl (Wanda). During the scene, we see the character building his Facebook profile with all the characteristics that he is not. He decides to meet her and give her a book as a gift. At the last minute, he decides not to meet her and instead leaves the book at a coffee shop. Not knowing that the coffee shop is owned by her mother, he goes there and strikes an instant connection with her mother. This scene introduces us to a netizen who steps into the real world. As digital scholar Poster (2002) explains, the netizen status is temporary because no one lives in the digital world permanently; eventually, any netizen will leave the virtual world and go back to their "normal" social status-and it is that encounter where the scene starts. We witness a virtual connection in the making between a man and a teenage girl, and a life connection is in process between the same man and the mother of the girl. The scene presents the participants' view of how social interactions works in both virtual life and reality: While it takes a long time and effort to develop the connection between the man and the girl in virtual life, the connection in real life was instant and more natural. Also, virtual life in the scene was characterized as being superficial and thus misrepresenting the self intentionally. 


\subsection{Second Scene}

In the second scene, we meet an international student who just moved to Europe, where we see her trying to talk to people in public spaces, in the street, in coffee shops, etc. However, she only faces disappointment and disregard from community members and decides to resort to online dating and strikes up a connection with a man. When she goes to see him, he does not appear. The scene then evolves in a random way where the international student gets to know a local friend who starts introducing her to the community and teaching her how to interact in the host community. The themes this scene poses are that of exclusion and inclusion; the character resorts to the digital world to find a solution for her exclusion in real life. Her main issue in the scene is that of assimilating herself in a live community that marginalizes her for being 'different'. Real life in this scene emerges as harsher than that on the internet. Unlike the first scene, where the character is dissembling as another persona online to be connected in the virtual world, the character in this scene uses her own personality in both the net and real life.

\subsection{Third Scene}

The third scene is about a person with a neutral mask. The character's name is simply 'person', and this person does not have a gender. Although he/she is in a perfectly healthy shape, he/she is sick from something. When he/she finally sees a doctor, the doctor diagnoses a "need to belong to someone" to cure him/herself. In the third scene, it's determined by a doctor that the problem 'person' is facing is a problem of belonging, and a problem of deciding what he or she needs to define him/her self now. A man? A woman? Christian? Muslim? etc.

\section{Discussion}

This project, in addition to its investigation on issues of netizenship, presents an innovative methodology to research a new form of interaction that is governing modern contemporary life. This interaction, based on virtual social connections, has the potential to divert citizens from their daily face-to-face connections towards online connections. While leading the workshop, facilitators invited participants to alternate between immersing themselves in a physical embodiment experience using applied theatre and theatre of the oppressed exercises (personality signature improvisations, and frozen image), and jumping back into the virtual world by asking them to engage and practice their netizenship during the workshop time.

In a modern life where everything is marked by "being pressured", social media becomes a platform where individuals have less social communication pressure. On such a platform, netizens are encouraged to open up, such as in the case of David in the first scene, and boost their self-confidence to form a new community. The dramatization of the stories of this workshop demonstrates that social media can foster virtual community belonging and the yearning to become part of a virtual community. Being immersed in social media indeed helps participants to keep up with old friends, build a social capital, and use online as a tool to get information; yet, human interaction was still the most powerful and the most efficacious, according to the participants' stories. This was particularly evident in the first story where the character was engaged for the whole time with a netizen online; however, the minute he met someone real, he forgot about his virtual connection.

The second story focuses on the issue of social inclusion, as a foreign student uses social media to both connect with her roots in her home and to break into her social life in her host community. The story was dramatized by the foreign student herself who acknowledged the many occasions that the workshop allowed her to create new social connections and thus build her social capital during the workshop, offering her a space for a personal transformation.

The third story presented a bleak image for someone who is fully immersed in the virtual. In that story, netizen's question of belonging becomes very evident where the character is not able to connect, the human desire to be belonging to something/someone was stronger than the virtual belonging that was presented in the story. This same metaphor of belonging was very evident in the performance where selected audience members were invited to see a presentation of the three scenes.

Facilitators work with a firm belief that art has always been a tool for change and in a world driven by digital world, the transformative effect of theater remains an authentic one. One of the participants said right after the performance ended that it is through physical embodiment, eye-to-eye contact, non-verbal communication that the performances came to life as the connections developed between everyone present that day (participants and audience members). Participants' embodiment and their stories created a heartwarming effect that left the facilitators, participants and audience in awe, and created what performance scholar Dolan (2001) calls utopian performative. In Dolan's description of utopian performative, she argues that theatre in general, whether applied or presented in a traditional form, offers tremendous communicative value. Theatre invites audience/participants 
to converse together and to engage in meaningful dialogue. It also allows audiences and participants to experience the unity that they share by being in the same place. Jill Dolan calls this communal feeling the utopian performative. According to Dolan, the utopian performative is a "feeling during performance that provides us with experiences of an ideal society" (Dolan, 2001, p. 455). When experienced in a community gathering, the utopian performative also enhances the feeling of belonging to a group; and according to Dolan, it is the combination of the liveliness, gathering, participating in the event and the immediacy of performance that create a utopian performative moment. Participants in this workshop acknowledge utopian performative moments that unite them as a group during theatre exercises and performance; such moments, help them build their social bond and belonging to the workshop community. Beyond the utopian performative and the transcendent experience of theatre, there is beauty of the real moment in time and space where people come together in a reality free from electronic devices. In a reflection session, participants were keen on stating that applied theatre and theatre of the oppressed techniques proved to be successful vehicles to investigate changing notions of netizenship and to challenge participants to rethink the role of social media in a rapidly changed world

As the doctor diagnoses the person in the last scene, it was clear for everyone who participated in the workshop that the question of belonging is the determinant issue of netizenship. We strive to belong and if we fail to belong in real life, we go to the virtual reality in order to belong. As the group expressed in the workshop, and in stories, the digital world has not yet shifted the focus of community members from real life to virtual life. As stated by workshop participants, at its best, the digital world is being used as a new way of connecting people and as a vast storage of information. In a final reflection session, participants expressed that applied theatre was an excellent tool for them to communicate their ideas about citizenship, belonging and social media. Most of the participants did not have theatre experience and yet that did not hinder them from participating in theatre activities. They attributed that to the encouraging and accepting environment that the facilitators created. One participant, an international student from Cambodia, had been having challenges assimilating within her surroundings and was feeling alienated in her new environment. She reported that the workshop helped her build social bonds and establishes meaningful connections with her colleagues that continue to be part of her new reality. This student's story becomes an example of what might lead to a transformative and positive change in the lives of a person who feels excluded and who is looking for opportunities to move from being a netizen to real life interaction.

\section{References}

Adler, P. S., \& Kwon, S.-W. (2002). Social Capital: Prospects for a New Concept. The Academy of Management Review, 27(1), 17. http://dx.doi.org/10.2307/4134367

Bimber, B. (2012). Digital Media and Citizenship. The SAGE Handbook of Political Communication, 115-126. http://dx.doi.org/10.4135/9781446201015.n10

Boal, A. (1985). Theatre of the oppressed. NewYork: Theatre Communications Group.

Carens, J. H. (1987). Aliens and Citizens: The Case for Open Borders. ROP, 49(02), 251. http://dx.doi.org/10.1017/s0034670500033817

Castro, D. (2008). Digital Quality of Life: Communities. SSRN Electronic Journal. http://dx.doi.org/10.2139/ssrn.1284987

Chachage, C. (2010). From Citizenship to Netizenship: Blogging for social change in Tanzania. Development, 53(3), 429-432. http://dx.doi.org/10.1057/dev.2010.54

Chambers, I. (2002). Citizenship, Language, and Modernity. PMLA, 117(1), 24-31. http://dx.doi.org/10.1632/003081202x63483

Cresswell, T. (2006). On the Move: Mobility in the Modern Western World. London: Routledge.

Dolan, J. (2001). Performance, utopian, and the utopian performatives. Theatre Journal, 53, 455-479.

Falk, R. (2000). The Decline of Citizenship in an Era of Globalization. Citizenship Studies, 4(1), 5-17. http://dx.doi.org/10.1080/136210200109997

Galston, W. A. (2001). Bowling Alone: The Collapse and Revival of American Community. J. Pol. Anal. Manage., 20(4), 788-790. http://dx.doi.org/10.1002/pam.1035

Hardy, B. W., \& Scheufele, D. A. (2007). New Media and Democratic Citizenship. Encyclopedia of Digital Government, 1250-1254. http://dx.doi.org/10.4018/978-1-59140-789-8.ch189

Hauben, M., \& Hauben, R. (1998). Preface: What is a Netizen? First Monday, 3(7). http://dx.doi.org/10.5210/fm.v3i7.606 
Hoffman, J. (2004). Citizenship beyond the state. London: SAGE.

Irwin, K. (2011). Staging the Internet: Representation (Bodies, Memories) and Digital Audiences. Canadian Theatre Review, 148(1), 54-60. http://dx.doi.org/10.1353/ctr.2011.0082

MacKinnon, R. (2012). The Netizen. Development, 55(2), 201-204. http://dx.doi.org/10.1057/dev.2012.5

Omotoyinbo, F. R. (2014). Online Radicalisation: The Net or the Netizen? Social Technologies, 4(1), 51-61. http://dx.doi.org/10.13165/st-14-4-1-04

Özlem, Y. (2014). Pre-Service Social Studies Teachers' Perspectives towards Netizenship. Turkish Online Journal of Educational Technology-TOJET, 13(2), 121-137.

Poster, M. (2002). Digital netwrok and citizenship. PMLA, 117(1), 98-103.

Rohd, M. (1998). Theatre for community, conflict \& dialogue: The hope is vital training manual. Portsmouth: Heinemann.

Taylor, P. (2003). Applied theatre: Creating transformative encounters in the community. Portsmouth: Heinemann.

Thompson, J. (2003). Applied theatre: Bewilderment and beyond. Bern: Peter Lang Publishing.

Wallack, L. (1993). Media advocacy and public health: Power for prevention. Newbury Park, California: Sage Publications.

\section{Notes}

Note 1. See the Future Places website $<$ http://futureplaces.org $>$ for full information regarding the festival and for a comprehensive archive of all their events and underpinning concepts.

Note 2. The festival is created and managed by Heitor Alvelos, Karen Gustafson, Nuno Correia and Pedro Branco.

Note 3. See the 2013 festival on the Future Places website under: <http://futureplaces.org/2013-futuredays/> for information specific to Future Days 2013.

\section{Copyrights}

Copyright for this article is retained by the author(s), with first publication rights granted to the journal.

This is an open-access article distributed under the terms and conditions of the Creative Commons Attribution license (http://creativecommons.org/licenses/by/3.0/). 